\title{
Relicthemisia, a new subgenus of the oil-collecting bee genus Centris Fabricius, 1804 with notes on distribution and host plants of $C$. xanthomelaena Moure \& Castro, 2001 (Hymenoptera: Apidae)
}

\author{
Felipe VIVALLO ${ }^{1}{ }^{1} \&$ Fernando César Vieira ZANELLA ${ }^{2, *}$ \\ ${ }^{1}$ HYMN, Laboratório de Hymenoptera, Departamento de Entomologia, Museu Nacional, \\ Universidade Federal do Rio de Janeiro, Quinta da Boa Vista, São Cristóvão 20940-040, \\ Rio de Janeiro, RJ, Brazil. \\ ${ }^{2}$ Pós-Graduação em Biodiversidade Neotropical, Universidade Federal da Integração \\ Latino-Americana, Av. Tarquinio Joslin dos Santos, 1000, Jardim Universitário, \\ 85867-000 Foz do Iguaçu, PR, Brazil. \\ *Corresponding author: fcvzanella@gmail.com \\ 1Email: fvivallo@yahoo.com \\ ${ }^{1}$ urn:lsid:zoobank.org:author:AC109712-1474-4B5D-897B-1EE51459E792 \\ ${ }^{2}$ urn:1sid:zoobank.org:author:8B9287C1-56A8-4DBC-964E-1022268C8BEB
}

\begin{abstract}
Centris xanthomelaena Moure \& Castro, 2001 is a relict species, endemic to northeastern Brazil and broadly recorded within the semiarid region of Caatinga xerophilous open vegetation. It was originally included in the subgenus Paracentris Cameron, 1903 but posteriorly interpreted as remotely related to it or to the subgenus Centris s. str. Fabricius, 1804. In this paper it is proposed to recognize this species as the single member of the monotypic Relicthemisia, a new subgenus which belongs to the 'Centris group', one of the main internal lineages of the genus. The proposition of this new subgenus is based on both, morphological and molecular data which indicate its long history as a distinct lineage. Distribution records, floral hosts as well as photographs of both sexes of C. xanthomelaena are also provided.
\end{abstract}

Keywords. Caatinga, Centridini, distribution, endemism, systematics.

Vivallo F. \& Zanella F.C.V. 2021. Relicthemisia, a new subgenus of the oil-collecting bee genus Centris Fabricius, 1804 with notes on distribution and host plants of C. xanthomelaena Moure \& Castro, 2001 (Hymenoptera: Apidae). European Journal of Taxonomy 760: 1-15. https://doi.org/10.5852/ejt.2021.760.1435

\section{Introduction}

Centris Fabricius, 1804 is one of the most abundant and diverse genus of solitary bees in the Neotropical Region. The taxonomy of this group is quite complex, mainly due to the lack of updated revisions, as well as the large number of described species. As a way to recognize apparently natural groups, several subgenera 
have been described in it, with Paracentris Cameron, 1903 being one of the most diverse, both in number of species and morphology (Vivallo 2020). According to the distribution pattern of the species of this subgenus, sensu Zanella (2002), it corresponds to a group with amphitropical distribution, with a large number of species occurring in North and South America, being practically absent in Central America (Michener 1979). The complete taxonomic revision of the species of Paracentris was published by Vivallo (2020), following the interpretation of Zanella (2002) who carried out a phylogenetic analysis using morphological data of a large part of the taxa present in South America.

Before that taxonomic revision, some species were included in Paracentris intuitively or for practical reasons. An example of this is the species of the 'hyptidis group' Vivallo \& Melo, 2009, whose species have been cited in the subgenera Ptilocentris Snelling, 1984; Centris. s. str.; Ptilotopus Klug, 1810; Wagenknechtia Moure, 1950; as well as in Paracentris (Moure et al. 2009), with the species of this group recently located in a new subgenus Anisoctenodes Vivallo, 2020. A similar case was also observed for Penthemisia Moure, 1950, synonymized with Paracentris by Snelling (1966) and still kept as a junior synonym by Michener (2007), which was later recognized as a distinct lineage exclusive from southern South America and reinstated as a distinct subgenus of Centris (Zanella 2002).

Another similar case is observed in a species apparently endemic to northeastern Brazil described as C. (Paracentris) xanthomelaena Moure \& Castro, 2001 and whose phylogenetic affiliation has remained uncertain until now. Moure et al. (2007) cited this species in the subgenus Paracentris, although the results obtained by Zanella (2002) indicated that it is not closely related to that subgenus, but it would correspond to a relict and undescribed lineage close to Centris s. str.

The phylogenetic relationships of $C$. xanthomelaena with other species of the genus were newly reconstructed by Martins \& Melo (2015) in a study using molecular characters. According to those authors, this species would correspond to a lineage not closely related to Centris s. str., but remotely related to the South American species of Paracentris. Despite this inconsistency, in both cases C. xanthomelaena appears as a relict and distinct lineage, which is part of a larger clade known as the 'Centris group' (Zanella 2002).

Considering the results obtained by Zanella (2002) and Martins \& Melo (2015), we formally propose a new monotypic subgenus, Relicthemisia subgen. nov., in this paper, containing C. xanthomelaena as type species and recognizing it as another of the major internal lineages of Centris. Both morphological and molecular evidence cited above support and justify the proposition of this new taxon.

\section{Material and methods}

General morphological terminology follows Michener (2007). Specimen labels were transcribed under the section 'Material examined'. The backward slash $(\backslash)$ indicates different labels on the pin of the specimen. Specimens marked with a cross ' $[\dagger]$ ' were lost in the fire of the Museu Nacional of Rio de Janeiro on September $2^{\text {nd }}, 2018$. The literature cited below the name of the species and above its diagnosis corresponds to an update of the information presented by Moure et al. (2007) in the Catalogue of Bees in the Neotropical Region.

Photographs were taken using a Leica DFC 450 camera attached to a Leica M205C stereo microscope and using extended-focus software Leica Application Suite ver. 4.8.0. All images were prepared using CombineZP ver. 7.0.0.1 software, and then enhanced with Adobe Photoshop ${ }^{\circledR}$ (ver. 7.0) without distorting the morphological characters of the specimens.

The distribution map was created using ArcView software (ver. 3.2 GIS) and prepared from locality records taken from specimen labels and from records available in literature listed in the section 'References'. The biogeographical provinces are according to Morrone (2014) and were implemented 
with the shape file provided by Löwenberg-Neto (2014). This was also done for the compilation of the floral records (Table 1). Plant names were checked and updated according to the International Plant Names Index (ipni.org). New distribution and/or floral records were marked with an asterisk (*).

\title{
Institutional abbreviations
}

DZUP = Coleção de Entomologia P.J.S. Moure, Departamento de Zoologia, Universidade Federal do Paraná, Curitiba, Paraná, Brazil

$\mathrm{LABE} / \mathrm{EBDA}=$ Laboratório de Abelhas da Empresa Bahiana de Desenvolvimento Agrícola, Salvador, Bahia, Brazil

MNRJ $=$ Museu Nacional, Universidade Federal do Rio de Janeiro, Rio de Janeiro, Brazil

RPSP = Coleção Entomológica 'Prof. J.M.F. Camargo', Universidade de São Paulo, Campus Ribeirão Preto, São Paulo, Brazil

UNILA = Coleção Entomológica Universidade Federal da Integração Latino-Americana, Foz do Iguaçu, Paraná, Brazil

\section{Results}

\section{Systematics}

\author{
Class Insecta Linnaeus, 1758 \\ Order Hymenoptera Linnaeus, 1758 \\ Family Apidae Latreille, 1802 \\ Tribe Centridini Cockerell \& Cockerell, 1901 \\ Genus Centris Fabricius, 1804 \\ Relicthemisia subgen. nov. \\ urn:1sid:zoobank.org:act:361E0AE3-2711-4089-974A-DA742A130E52
}

Figs $1-4$

\section{Type species}

Centris xanthomelaena Moure \& Castro, 2001

\section{Diagnosis}

Integument dark brown to black, clypeus and labrum coriaceous with coarse and dense punctation, but the clypeus with an unpunctated area as a median longitudinal band on upper half(Fig. 1A).

\section{Female}

Inner orbits of compound eyes converging downward (Fig. 1A). Mandible with four apically acute teeth, the fourth tooth slightly larger than the third (Fig. 1A). Basitibial plate elliptical, with S-like secondary plate (Fig. 2A). Elaiospathes normally developed.

\section{Male}

Clypeus, except lateral areas, and labrum yellow (Fig. 1C). Yellow spots on paraocular and supraclypeal areas (Fig. 1C). Apical margin of T7 with strong emargination (Fig. 2B). S7 without emargination on the basal border (Fig. 2B). S8, apical projection clearly defined, larger at middle and with rounded apex (Fig. 2C). Genital capsule with long dorsoapical projection of gonocoxite, ca 2/3 lengths of gonostylus (Fig. 2E).

\section{Etymology}

From Latin 'relictus' (a survivor from a previous age) plus 'Hemisia' (a junior synonym of Centris) due to the antiquity and isolation of this lineage. 


\section{Remarks}

Centris xanthomelaena, the only species of the new subgenus Relicthemisia, was recognized as a distinct lineage with no close relationship to other species, based on morphological (Zanella 2002) and molecular data (Martins \& Melo 2015). Depending on the study, the phylogenetic position of this lineage was different, either as sister group of Centris s. str. or Paracentris Cameron, 1903 respectively. Nevertheless, it was always recovered as a distinct and relatively old lineage within the 'Centris group'. According to Martins \& Melo (2015), C. xanthomelaena diverged from a South American clade formed by Paracentris around 18 million years ago, at about the same time when the major lineages within the 'Centris group' diverged from each other.

The hypothetical relationship of this species with Centris s. str. was based on the interpretation of two morphological characters: the strong emargination on the apical margin of T7 (Fig. 2B; character 25: 0 in Zanella 2002) and the short and wide translucent laminar projection on the dorsodistal region of the gonocoxite at the base of the long, giant bristles (Fig. 2E-F; character 44: 1 in Zanella 2002), but the states present in C. xanthomelaena are clearly unique and cannot be homologous to those present in species of Centris s. str.

Despite the fact that new phylogenetic analyses using a higher number of terminals of Centris s. str. and Paracentris can provide new information regarding the history and relatedness of the lineage of C. xanthomelaena, its distinctness and old history are well supported (see Martins \& Melo 2015). Besides the uniqueness of the intense yellow slightly greenish pilosity covering the head, mesosoma (except the ventral surface) and on the anterior half of T1 that allow to easily recognize C. xanthomelaena from other species of the genus (Fig. 1A-D), this monotypic subgenus presents a unique combination of characters of the male's genitalia that distinguishes it from the other members of the 'Centris group': an emargination on the apical margin of T7 (Fig. 2B); a long dorsoapical projection of gonocoxite, ca $2 / 3$ lengths of gonostylus (Fig. 2E); the dorsomedial projections of the genital capsule (Fig. 2E), as well as the S-like lower margin of the female's secondary basitibial plate (Fig. 2A).

Centris (Relicthemisia) xanthomelaena Moure \& Castro, 2001

Figs $1-4$

Centris 'xanthomelaena' Vogel \& Machado, 1991: 163-175, figs 6a-b, 9a, h (distribution, floral records, pollination). Nomen nudum.

Centris (Paracentris) xanthomelaena - Moure \& Castro 2001: 330-332, figs 1-4 (original description). - Silveira et al. 2002: 98, 253 (distribution, list). - Urban 2003: 24, 43 (taxonomic note, cited). - Azevedo \& Silveira 2005: 45 (cited). - Batalha Filho et al. 2007: 25 (distribution record). - Moure et al. 2007: 120 (catalogue). - Azevedo et al. 2008: 143 (distribution record). — Machado \& Sazima 2008: 488 (floral record). — Rodarte et al. 2008: 307 (distribution record). - Pigozzo \& Viana 2010: 105 (distribution record). — Vivallo \& Zanella 2012: 4, 6, 8-9, 13 14, figs 37-38, 77-78 (distribution, key). - Giannini et al. 2013: 78 (list). - Silva 2014: 188 (distribution record). - Martins et al. 2018: 770, figs 1-2 (bionomy, nesting behavior, distribution record). - Barenbaum 2019: 222 (bionomy, sleeping behavior). - Carneiro et al. 2019: 219 (distribution and floral records).

Centris xanthomelaena - Zanella 2002: 438, 444, 447, 451, 453, 455, 457, 459, 483, 485, 486, figs 26, 164-170 (diagnosis, male description, distribution map, morphological characters, phylogenetic relationships). - Aguiar 2003a: 42, 43 (distribution and floral records); 2003b: 464 (floral record). —Zanella 2003: 234 (list). — Aguiar et al. 2005: 249 (distribution record). — Aguiar \& Zanella 
2005: 17, 19 (distribution record). - Azevedo \& Silveira 2005: 47 (cited). - Prevedello \& Carvalho 2006: 45 (cited). — Zanella \& Vivallo 2009: 68 (cited). — Martins \& Melo 2015: 7-8, 10 (phylogenetic relationships). - Martins et al. 2018: 771, 772 (sleeping behavior). — Carneiro et al. 2019: 216, 220 (distribution and floral records, pollinator).

\section{Diagnosis}

\section{Female}

Integument dark brown to black, except flagellum dark brown and tegula yellowish brown (Fig. 1A-B). Wings brown with veins dark brown (Fig. 1B). Head, mesosoma (except the ventral surface) and anterior half of T1 with intense yellow slightly greenish pilosity, lighter on labrum and gena (Fig. 1A-B). The rest of the body with blackish hairs, except posterior apex of the femur of forelegs with some yellowish hairs (Fig. 1A-B). Clypeus coriaceous with coarse and dense punctation (Fig. 1A). Clypeal disc with an unpunctated area on upper half, without smooth longitudinal band. Labrum with the same punctation, but denser, without smooth basal margin. Terga and sterna, except T6 and S6, with very narrow smooth distal margin, wider on T4. Mandible with four apically acute teeth (Fig. 1A). Fourth teeth slightly larger
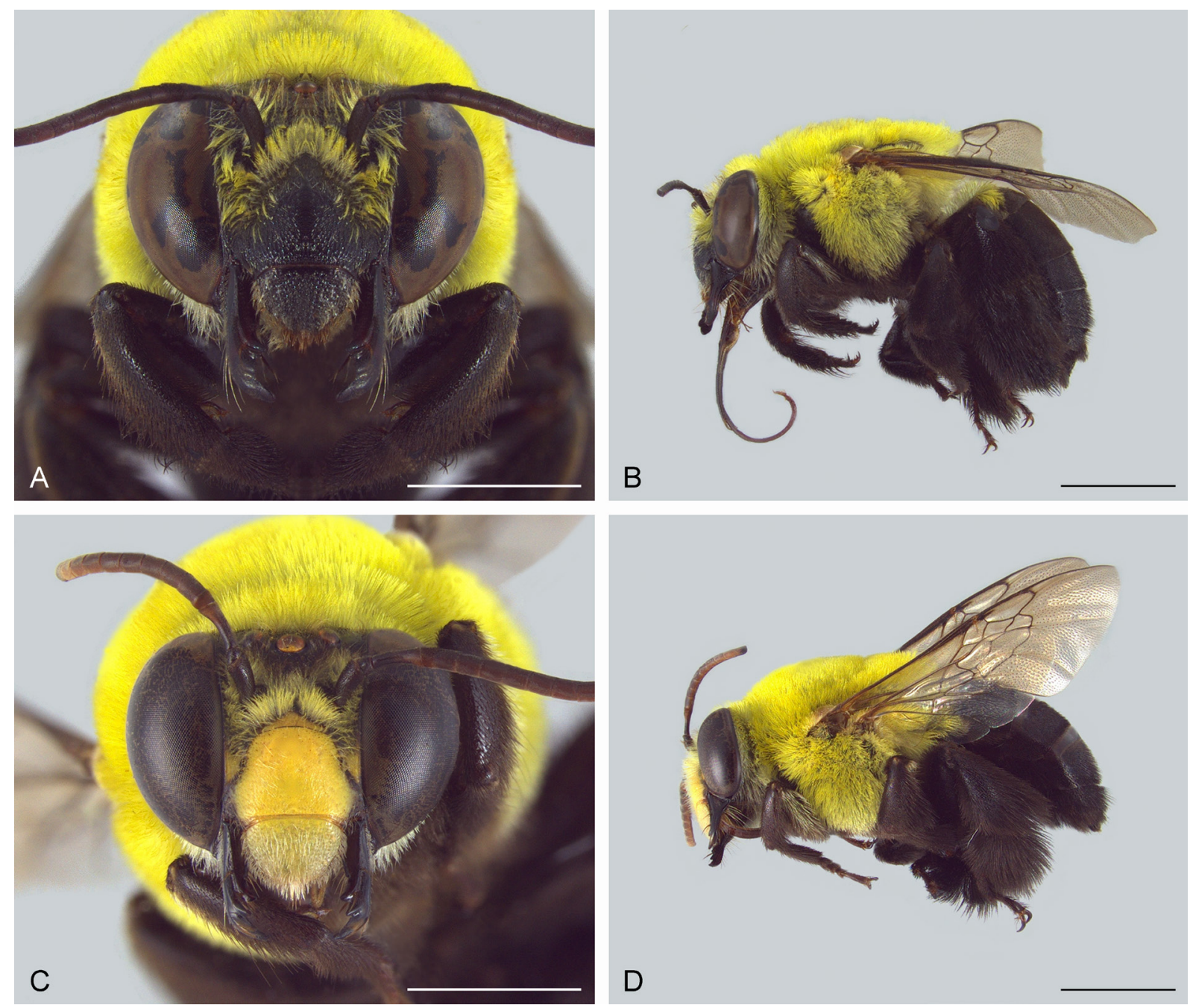

Fig. 1. Centris (Relicthemisia) xanthomelaena Moure \& Castro, 2001. A-B. + . A. Frontal view. B. Habitus, lateral view. C-D. $\overbrace{}^{\Uparrow}$. C. Frontal view. D. Habitus, lateral view. Scale bars: A, C $=2 \mathrm{~mm}$; $\mathrm{B}, \mathrm{D}=5 \mathrm{~mm}$. 
than the third (Fig. 1A). Maxillary palpus 4-segmented. Malar area very narrow (Fig. 1A). Labrum semicircular (Fig. 1A). Inner orbits of compound eyes converging downward (Fig. 1A). Elaiospathes normally developed. Basitibial plate elliptical, with S-like secondary plate (Fig. 2A). S2-S4 projected in the middle. Apex of primary pygidial plate slightly rounded with the apex of the secondary plate open and slightly projected towards the distal edge of the primary plate (Fig. 2D).

\section{Male}

Similar to the female, except for the following characters: integument dark brown to black, except basal segments of the flagellum brown and apical segments slightly orange (Fig. 1C-D). Supraclypeal area, discs of clypeus and labrum yellow (Fig. 1C-D). Tegula yellowish brown. Clypeal disc with small unpunctated area on upper half, without smooth longitudinal band. Terga and sterna, except T7 and S6, with relatively broad light brown smooth distal margin, wider on T4. Mandible with three apically acute teeth (Fig. 1C). Distance between clypeus and compound eyes shorter than half of the shortest diameter of F1 (Fig. 1C). Apical margin of the hind tibia without tooth-like projection. Apical half of fore and middle basitarsi without a row of long, erect, slightly spatulate and curved setae similar to an elaiospathe. Pygidial plate absent.

A
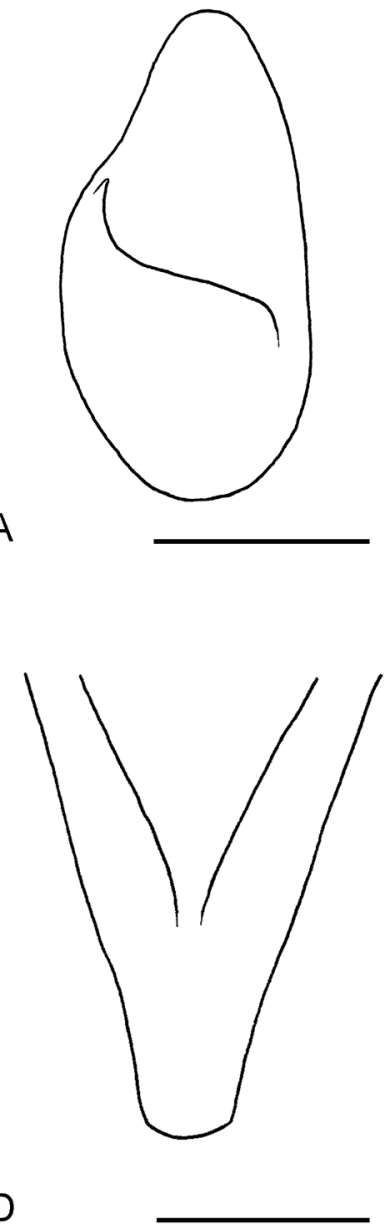

D

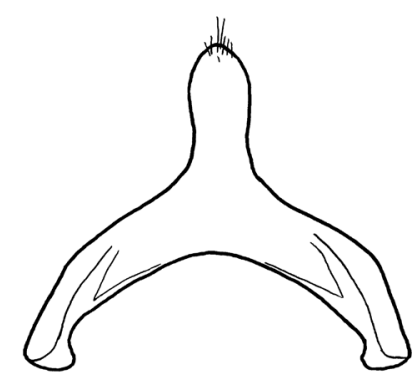

B

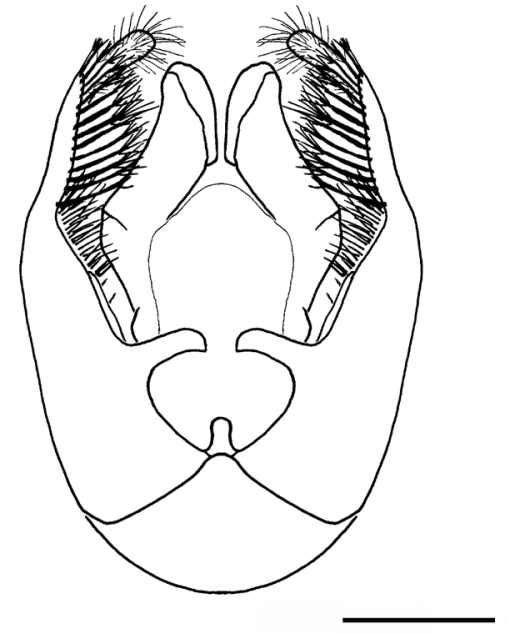

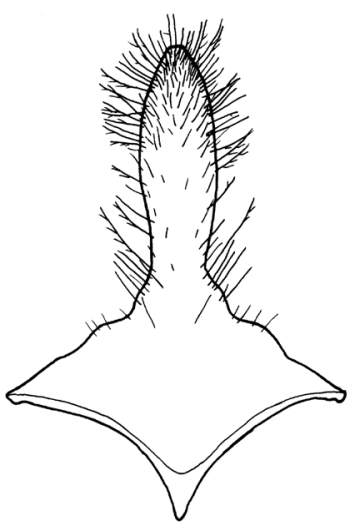

C

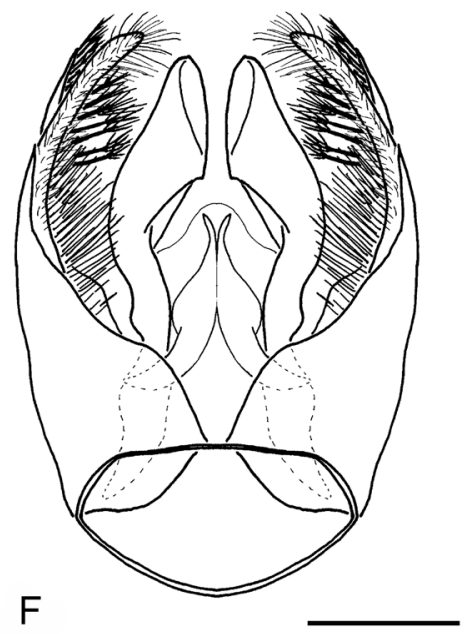

Fig. 2. Morphological characteristics of Centris (Relicthemisia) xanthomelaena Moure \& Castro, 2001. A. Female basitibial plate. B. Male S7. C. Male S8. D. Female pygidial plate. E. Genital capsule (dorsal view). F. Genital capsule (ventral view). Scale bars $=0.5 \mathrm{~mm}$. 


\section{Type material}

\section{Holotype}

BRAZIL - Bahia State - ; Milagres; 28 Jan. 1998; 10h50; Marina Siqueira de Castro leg.; Chamaechrista amiciela (Caesalpiniaceae) $\backslash 1070$; LABE/EBDA (not examined).

\section{Paratypes}

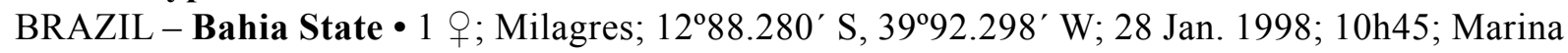
Siqueira de Castro leg.; Chamaechrista amiciela (Caesalpiniaceae) $\backslash 1069$; LABE/EBDA (not examined) • 1 क; Milagres; $12^{\circ} 88.280^{\prime}$ S, 3992.298' W; 31 Mar. 1997; 10h30; Marina Siqueira de Castro leg.; in Stimaphyllom auriculatum (Malpighiaceae); DZUP (not examined).

\section{Material examined}

(specimens labeled as paratype or holotype below do not belong to the type series)

BRAZIL - Alagoas State - 1 क; Piranhas, Poço da Ingazeira; 950.594' S, 3788.113' W; 28 Oct. 2005; Debora Moura leg.; “Centris xanthomelaena Moure \& Castro 2001 Schlindwein Det." \HYAP 4004; UNILA. - Bahia State • 1 q; Curaçá, Faz. Humaitá; 907'262" S, 39²42 859" W; $440 \mathrm{~m}$ a.s.l.; 4 May 2011; PPBIO Caatinga; F.C.V. Zanella leg.; \HYAP 0582, UNILA • 1 \%; Monte Santo; $10^{\circ} 43.958^{\prime}$ S, 39³3.566' W; 3 Feb. 2000; w.c.; Malpighiaceae $\backslash$ HYAP 9706, UNILA

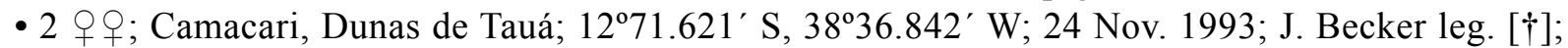

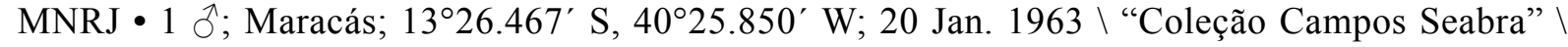
J. Becker leg. \"Centris Xanthemisia bicolor Lepeletier" \ "C. Paracentris xanthomelaena A.A.

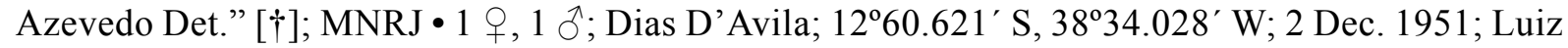

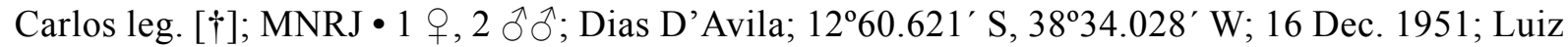

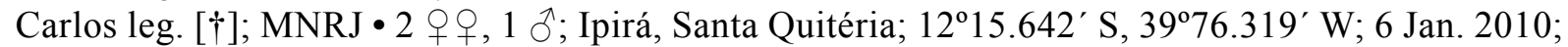
K. Ramos and V. Kanamura leg. [†]; MNRJ. - Minas Gerais State - 1 q; Conego Marinho;

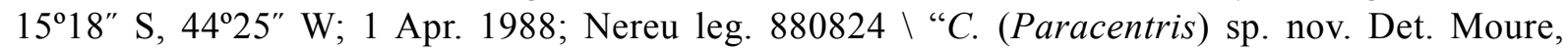
1992" “Parátipo Centris xanthomelaena sp. nov. F. Zanella, 1999”; RPSP • 1 ð’; Conego Marinho;

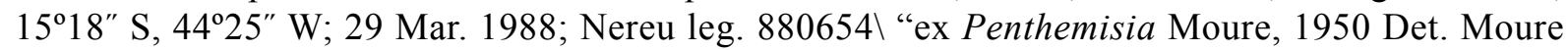
1992" \“C. (Paracentris) sp. nov. Det. Moure, 1998” \"Parátipo Centris xanthomelaena sp. nov. F. Zanella, 1999”; RPSP. - Paraíba State • 1 o ; Patos; 703.860’ S, 37³1.445’ W; 16 Aug. 2002; Gisllyana leg.; HYAP 9300; UNILA. - Pernambuco State - 1 क; Alagoinha; $8^{\circ} 46.622^{\prime}$ S, 36²78.423' W; 18 Jun. 1987; I.C.S Machado leg.; in Ruellia sp. ' “C. (Paracentris) sp. nov., Det. Moure 1992" ‘ "Holótipo Centris xanthomelaena sp. nov. F. Zanella, 1999”; RPSP・ 1 q; Buique, Vale do Catimbau; 849.210' S, 3750.180' W; 17 Mar. 2005; R. Pick leg. \ “Centris xanthomelaena Moure \& Castro 2001 Schlindwein Det." ।; HYAP 4002; UNILA. - Rio Grande do Norte State • $1 \partial^{7}$; Serra Negra do Norte, ESEC Seridó; 666.572' S, 37040.515' W; 12 Aug. 1995; F. Zanella leg.l 0938 10b03\ HYAP 9705; UNILA • 2 우; Serra Negra do Norte, ESEC; 6º6.572' S, 37040.515' W; 13 Mar. 2005; F. Zanella leg.; em pl. 1 roxa 10h $\backslash$ HYAP 4601; UNILA • 1 خे; Serra Negra do Norte, ESEC Seridó; 666.572’ S, 37040.515' W; 5 Jul. 2005; F. Zanella leg.; pl. 27 Chamaechrista 13h \HYAP 4598; UNILA • 1 क ; Serra Negra do Norte, ESEC Seridó; $6^{\circ} 66.572^{\prime}$ S, 37040.515' W; 22 May 2005; F. Zanella leg. \HYAP 4600; UNILA • 1 क; Serra Negra do Norte, ESEC Seridó; $6^{\circ} 66.572^{\prime}$ S, $37^{\circ} 40.515^{\prime}$ W; 12 Jun. 2005; F. Zanella leg.; Krameria sp. 14h \HYAP 4853; UNILA

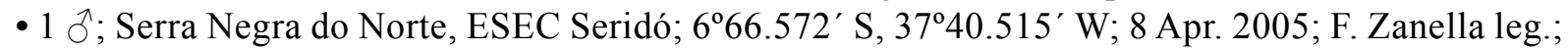
Voando sobre arbusto 17h [†]; MNRJ • 1 क; Santana do Seridó; 6²4" S, 36 44" W; 10 Aug. 2007; J.M.F. Camargo leg.; 07.1024; RPSP.

\section{Type locality}

Brazil: Bahia State: Milagres. 


\section{Distribution}

Endemic to northeastern Brazil, being recorded mainly in the dry open Caatinga vegetation (Fig. 3). The only record in central Brazil, Mato Grosso State, needs confirmation. Brazil: Rio Grande do Norte State: Serra Negra do Norte (Zanella 2002, 2003; Aguiar et al. 2003; Silva 2014), *Santana do Seridó. Paraíba State: (Silveira et al. 2002). *Patos. Pernambuco State: Alagoinha (Vogel \& Machado 1991; Machado \& Sazima 2008). Petrolina (Xavier et al. 2016; Martins et al. 2018). Salgueiro (Xavier et al. 2016). *Buique. Alagoas State: *Piranhas. Bahia State: Canudos (Pigozzo \& Viana 2010; Silva 2014). Ibiraba (Rodarte et al. 2008). Itatim (Aguiar 2003a, 2003b; Aguiar et al. 2003; Aguiar \& Zanella 2005; Silva 2014). Jequié (Batalha Filho et al. 2007; Silva 2014). Juazeiro (Coelho et al. 2018). Milagres (Moure \& Castro 2001; Silva 2014). Monte Santo (Zanella 2002; Aguiar et al. 2003). Xique-Xique (Carneiro et al. 2019). *Camacari (Dunas de Tauá), *Dias D’Ávila, *Ipirá (Santa Quitéria), *Maracás. Mato Grosso State: cf. Serra do Roncador (Zanella 2002). Minas Gerais State: Botumirim (Azevedo et al. 2008). Cônego Marinho (Zanella 2002).

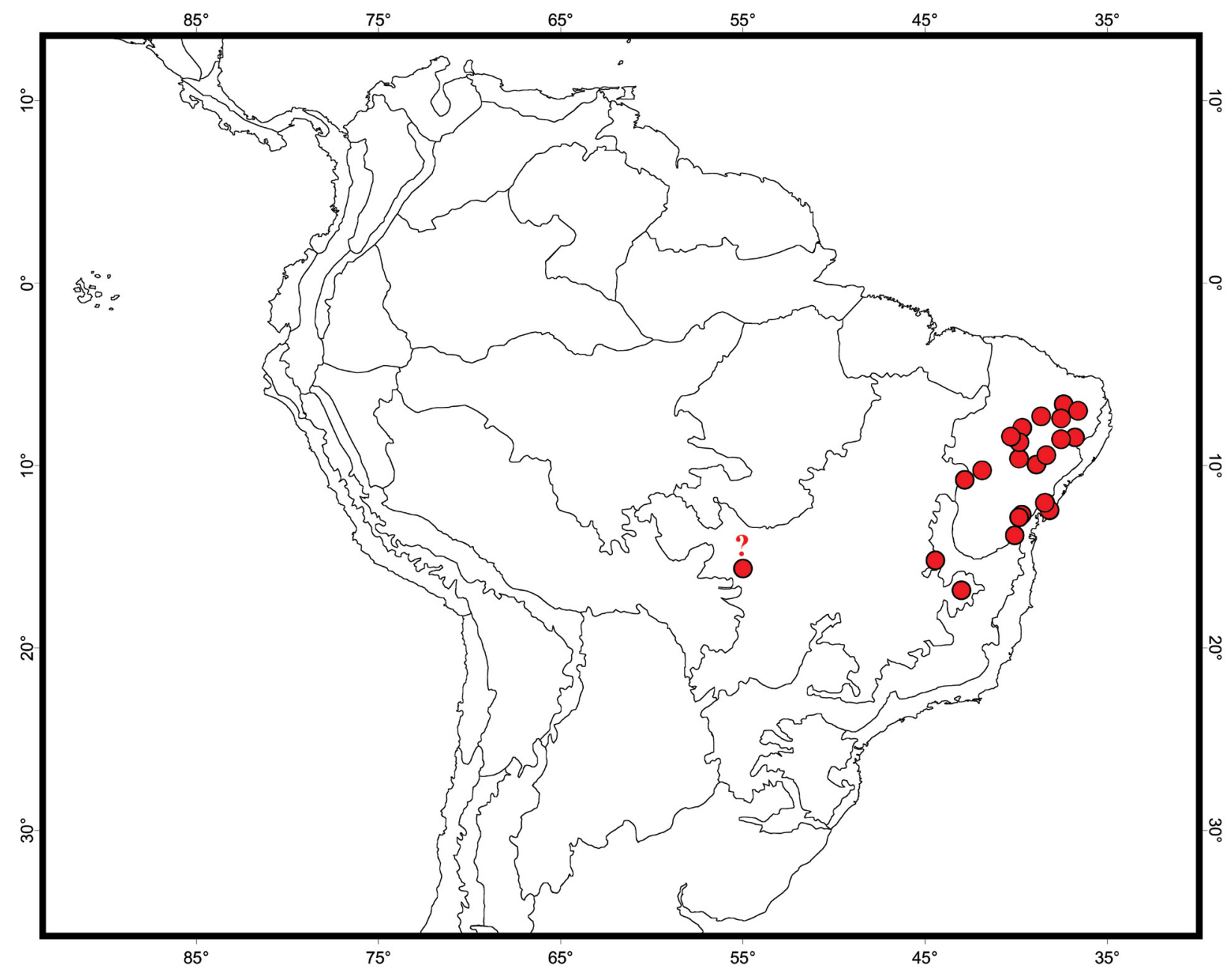

Fig. 3. Distribution records of Centris (Relicthemisia) xanthomelaena Moure \& Castro, 2001. The limits of biogeographical provinces are depicted in the map. Most records of this species are found in the Caatinga province in northeastern Brazil and marginally in the Cerrado Province, both in the South American diagonal of dry open areas. 
Table 1. Floral host records for Centris (Relicthemisia) xanthomelaena Moure \& Castro, 2001 and distribution of host plant species.

\begin{tabular}{|c|c|c|c|}
\hline Plant family and species & $\begin{array}{c}\text { Main resource } \\
\text { (elaiophore type) }\end{array}$ & $\begin{array}{c}\text { Vegetation and distribution } \\
\text { of host plant species }{ }^{1,2}\end{array}$ & $\begin{array}{l}\text { Host plant } \\
\text { record }^{1}\end{array}$ \\
\hline \multicolumn{4}{|l|}{ Acanthaceae } \\
\hline *Ruellia sp. & Nectar & $?$ & $(\mathrm{H})$ \\
\hline sp.? & Nectar & $?$ & (I) \\
\hline \multicolumn{4}{|l|}{ Fabaceae } \\
\hline $\begin{array}{l}\text { Chamaecrista amiciella } \\
\text { (H.S. Irwin \& Barneby) } \\
\text { H.S. Irwin \& Barneby }\end{array}$ & Pollen & $\begin{array}{l}\text { Caatinga in Northeast Brazil } \\
\text { and in GO state (A) }\end{array}$ & $(\mathrm{J})$ \\
\hline $\begin{array}{l}\text { C. pascuorum (Benth.) } \\
\text { H.S. Irwin \& Barneby }\end{array}$ & Pollen & $\begin{array}{c}\text { Caatinga, 'campo rupestre' and } \\
\text { anthropized area in Northeast Brazil } \\
\text { and MG state (A) }\end{array}$ & (I) \\
\hline Chamaecrista sp. & & $?$ & $(\mathrm{H})$ \\
\hline \multicolumn{4}{|l|}{ Krameriaceae } \\
\hline $\begin{array}{l}\text { Krameria grandiflora } \\
\text { A. St. Hill. }\end{array}$ & Oil (epithelial) & $\begin{array}{l}\text { Caatinga, 'campo rupestre', restinga, } \\
\text { cerrado (lato sensu) anthropized area } \\
\text { from PA and RN to MS } \\
\text { and ES states in Brazil (B) }\end{array}$ & $(\mathrm{K})$ \\
\hline Krameria sp. (Fig. 4) & Oil (epithelial) & $?$ & $(\mathrm{~L}, \mathrm{H})$ \\
\hline \multicolumn{4}{|l|}{ Malpighiaceae } \\
\hline $\begin{array}{l}\text { Mcvaughia bahiana } \\
\text { W.R. Anderson }\end{array}$ & Oil (epithelial) & Sandy Caatinga in BA state $(\mathrm{C})$ & $(\mathrm{I}, \mathrm{M})$ \\
\hline $\begin{array}{l}\text { Stigmaphyllon auriculatum } \\
\text { A. Juss. }\end{array}$ & Oil (epithelial) & $\begin{array}{l}\text { Caatinga and restinga in Northeast } \\
\text { Brazil and ES and RJ states (D) }\end{array}$ & $(\mathrm{J})$ \\
\hline \multicolumn{4}{|l|}{ Plantaginaceae } \\
\hline $\begin{array}{l}\text { Angelonia campestris } \\
\text { Nees \& Mart. (= bisaccata } \\
\text { Benth. = hookeriana } \\
\text { Gardner ex Benth.) }\end{array}$ & Oil (trichomatic) & $\begin{array}{c}\text { Caatinga and 'campo rupestre' } \\
\text { in Northeast Brazil (E) }\end{array}$ & $(\mathrm{I}, \mathrm{L}, \mathrm{M})$ \\
\hline $\begin{array}{l}\text { A. salicariifolia Bonpl. } \\
\text { (= hirta } \text { Cham.) }\end{array}$ & Oil (trichomatic) & $\begin{array}{c}\text { Caatinga in Northeast Brazil } \\
\text { and Cerrado (lato sensu) } \\
\text { in MS state }(\mathrm{E}) \text {, reaching Argentina } \\
\text { and Central America }(\mathrm{F})\end{array}$ & $(\mathrm{I}, \mathrm{L}, \mathrm{M})$ \\
\hline \multicolumn{4}{|l|}{ Sterculiaceae } \\
\hline Melochia tomentosa L. & Nectar & $\begin{array}{l}\text { Anthropized area, cerrado (lato sensu), } \\
\text { rocky outcrops and rain forest } \\
\text { in Northeast and Midwest Brazil }(\mathrm{G})\end{array}$ & $(\mathrm{I}, \mathrm{N}, \mathrm{O})$ \\
\hline
\end{tabular}

${ }^{1}$ References for plant species distribution and host plant record: (A) Souza \& Bortoluzzi 2015; (B) Costa-Lima 2020; (C) Almeida et al. 2019; (D) Mamede 2015; (E) Souza et al. 2020; (F) Martins \& Alves-dos-Santos 2013; (G) Esteves 2015. References for plant hosts: (H) this work; (I) Aguiar et al. 2003; (J) Moure \& Castro 2001; (K) Carneiro et al. 2019; (L) Machado 2004; (M) Vogel \& Machado 1991; (N) Aguiar 2003a, 2003b; (O) Machado \& Sazima 2008.

${ }^{2}$ Brazilian states: BA: Bahia, ES: Espírito Santo, GO: Goiás, MG: Minas Gerais, MS: Mato Grosso do Sul, PA: Pará, RJ: Rio de Janeiro, RN: Rio Grande do Norte.

${ }^{3}$ Cited as Macvaughia bahiensis, a name that does not appear in ipni.org. 


\section{Discussion}

The distinctiveness of Centris xanthomelaena as compared with the previously described subgenera of Centris was already characterized by Zanella (2002), especially based on the analysis of male genitalia. In the key for subgenera of Centris of Michener (2007), this species fits in Paracentris, considering the "female's basitibial plate with defined secondary plate that lacks sharp projecting margin" and the "margin of secondary plate extending [...] near posterior margin of basitibial plate" (dilemma 13), while the male's lateral ocellus is separated from the eyes by a distance similar to the ocellar diameter, and the T2-T4 covered with dark pubescence (dilemma 20). Nevertheless, males of C. xanthomelaena are clearly distinguished from males of Paracentris by the strong emargination on the apical margin of T7 (Fig. 2B), by the absence of emargination on the basal border of S7 (Fig. 2B), and by the presence of a long dorsoapical projection of gonocoxite, ca $2 / 3$ lengths of gonostylus (Fig. 2E-F). This latter feature is unique, being a somewhat intermediate condition between that observed in Centris s. str. and Paracentris.

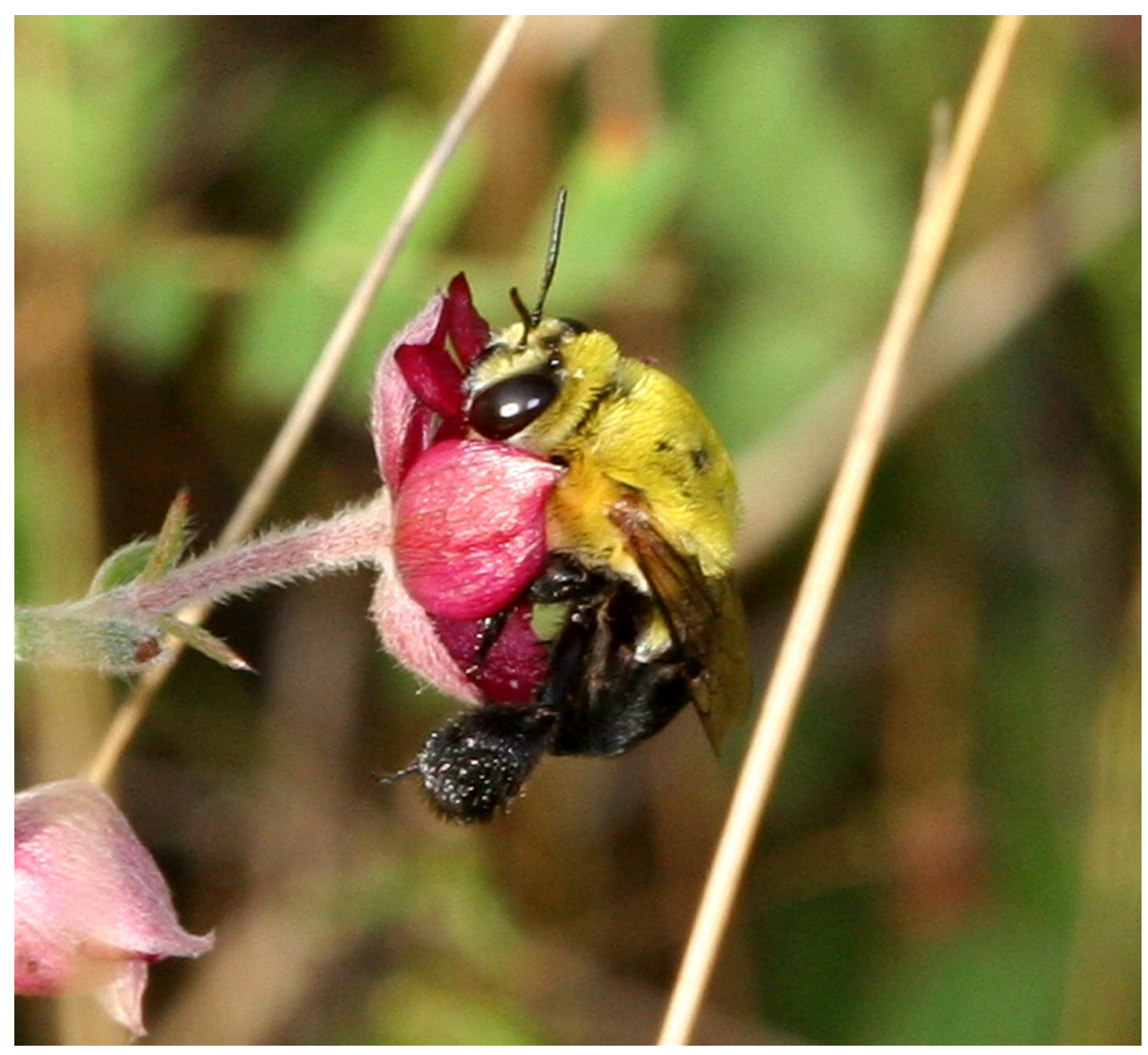

Fig. 4. Female of Centris (Relicthemisia) xanthomelaena Moure \& Castro, 2001 visiting Krameria sp. (Krameriaceae) in Estação Ecológica do Seridó, Rio Grande do Norte State, Brazil. 
Previously to its description and naming, Centris xanthomelaena was already recognized as a legitimate pollinator of Angelonia campestris Nees \& Mart. and A. salicariifolia Bonpl. (Plantaginaceae) in the Caatinga (Vogel \& Machado 1991). The two pollen sources Chamaecrista Moench species and oil sources Krameria grandiflora A. St. Hill., Mcvaughia bahiana W.R. Anderson, Stigmaphyllon auriculatum A. Juss. and A. campestris are endemic to northeastern Brazil and specially recorded in xerophilous Caatinga vegetation or at least in open vegetation areas.

A similar context was noted by Aguiar et al. (2003) in relation to Centris hyptidis Ducke, 1908, another species endemic from northeastern Brazil and typical from Caatinga vegetation. This species also has a more specialized relation with pollen and oil sources in the Caatinga biome as compared to other species with wider distribution patterns. This can be interpreted as a result of a longer history with plants of this semiarid region. Differing from the interpretation of Giannini et al. (2013), C. hyptidis, along with C. hyptidoides Roig-Alsina, 2000 and C. thelyopsis Vivallo \& Melo, 2009, does not belong to the same lineage of the subgenus Wagenknechtia, but to $C$. (Anisoctenodes), an old lineage distributed in the South American diagonal of open dry vegetation (Werneck 2011; Zanella 2011), probably with association to flowers of Angelonia (Plantaginaceae) (Vivallo \& Melo 2009; Martins \& Melo 2015).

A similar old history and restricted distribution is found in Centris (Relicthemisia) xanthomelaena, in spite of similar oil-collecting apparatuses found in other species of Centris that also occur in the Caatinga (Vogel \& Machado 1991). Those structures are specialized in exploring plant species with epithelial elaiophores (Giannini et al. 2013). It must also be noted that there is no record of this bee visiting the introduced West Indian cherry (Malpighia emarginata D.C.) even though the intense collection effort in this tree at sites where C. (Relicthemisia) xanthomelaena occurs (Coelho et al. 2018; Siqueira et al. 2011).

\section{Acknowledgments}

We thank Eduardo A.B. Almeida (RPSP), Diego Marinho (MNRJ) and the anonymous reviewers for their help. Financial support was provided to Felipe Vivallo by Conselho Nacional de Desenvolvimento Científico e Tecnológico (CNPq, grant 444320/2014-8) and Projeto de Informatização da Coleção Entomológica do Museu Nacional/UFRJ, SIBBR/CNPq (proc. 405588/2015-1), Brazil. Support for studies in the Caatinga region was provided to Fernando Zanella by Programa de Pesquisa em Biodiversidade Semiárido do Ministério da Ciência e Tecnologia (PPBio Semiárido), by Fundação de Apoio à Pesquisa da Paraíba (FAPESQ) and CNPq, on the project 'Diversidade, Ecologia e Conservação de Himenópteros na Região Semiárido do Nordeste do Brasil, com ênfase nas Abelhas'. This study was registered at Sistema Nacional de Gestão do Patrimônio Genético e do Conhecimento Tradicional Associado under number A6F40C4. This paper is part of the SIGMA project $\mathrm{N}^{\circ} 21565 \mathrm{MN} / \mathrm{UFRJ}$ and the contribution number 57 from the HYMN.

\section{References}

Aguiar C.M.L. 2003a. Flower visits of Centris bees (Hymenoptera: Apidae) in an area of Caatinga (Bahia, Brazil). Studies on Neotropical Fauna Environment 38: 41-45.

https://doi.org/10.1076/snfe.38.1.41.14029

Aguiar C.M.L. 2003b. Utilização de recursos florais por abelhas (Hymenoptera, Apoidea) em uma área de Caatinga (Itatim, Bahia, Brasil). Revista Brasileira de Zoologia 20: 457-467. https://doi.org/10.1590/S0101-81752003000300015

Aguiar C.M.L. \& Zanella F.C.V. 2005. Estrutura da comunidade de abelhas (Hymenoptera: Apoidea: Apiformes) de uma área na margem do Domínio da Caatinga (Itatim, BA). Neotropical Entomology 34: 15-24. https://doi.org/10.1590/S1519-566X2005000100003 
Aguiar C.M.L., Zanella F.C.V., Martins C.F. \& Carvalho C.A.L. 2003. Plantas visitadas por Centris spp. (Hymenoptera: Apidae) na Caatinga para obtenção de recursos florais. Neotropical Entomology 32: 247-259. https://doi.org/10.1590/S1519-566X2003000200009

Aguiar C.M.L., Gimenes M. \& Rebouças P.L.O. 2005. Abelhas (Hymenoptera, Apoidea). In: Juncá F.A., Funch L. \& Rocha W. (eds) Biodiversidade e Conservação da Chapada Diamantina: 259-277. Ministério do Meio Ambiente, Brazil.

Almeida R.F., Guesdon I.R., Pace M.R. \& Meira R.M.S. 2019. Taxonomic revision of Mcvaughia W.R. Anderson (Malpighiaceae): notes on vegetative and reproductive anatomy and the description of a new species. PhytoKeys 117: 45-72. https://doi.org/10.3897/phytokeys.117.32207

Azevedo A.A. \& Silveira F.A. 2005. Two new species of Centris (Trachina) Klug, 1807 (Hymenoptera: Apidae) from the state of Minas Gerais, Brazil, with a note on Centris pachysoma Cockerell, 1919. Lundiana 6: 41-48.

Azevedo A.A., Silveira F.A., Aguiar C.M.L. \& Pereira V.S. 2008. Fauna de abelhas (Hymenoptera, Apoidea) nos campos rupestres da Cadeia do Espinhaço(Minas Gerais e Bahia, Brasil): riqueza de espécies, padrões de distribuição e ameaças para conservação. Megadiversidade 4: 126-157. Available from https:/www.conservation.org/docs/default-source/brasil/megadiversidade_espinhaco.pdf[accessed1May2020].

Barenbaum M. 2019. Catching ZZZZs. American Entomologist 65: 220-222.

https://doi.org/10.1093/ae/tmz060

Batalha Filho H., Nunes L.A., Pereira D.G. \& Waldschmidt A.M. 2007. Inventário da fauna de abelhas (Hymenoptera, Apoidea) em uma área de Caatinga da região de Jequié, BA. Bioscience Journal 23: 24-29. Available from http://www.seer.ufu.br/index.php/biosciencejournal/article/view/6801 [accessed 16 Jun. 2021].

Cameron P. 1903. Descriptions of new species of Hymenoptera taken by Mr Edward Whymper on the 'higher Andes of the Equator'. Transactions of the American Entomological Society 29: 225-328.

Carneiro L.T., André C.B.D., Takahasi A. \& Alves-dos-Santos I. 2019. Interactions between oil-collecting bees and Krameria grandiflora (Krameriaceae) with emphasis on the role of specialized floral traits in the mutual fit. Arthropod Plant Interactions 13: 213-226. https://doi.org/10.1007/s11829-019-09689-w

Coelho W.S.S., Silva R.C.S., Souza G.C.S., Araújo K.L.G. \& Kiill L.H.P. 2018. Diversidade de visitantes florais em duas variedades de aceroleira em cultivos comerciais, em Juazeiro, BA. In: Anais da XIIIJornada de Iniciação Científica da Embrapa Semiárido, EMBRAPA Semiárido, Petrolina: 47-52. Available from https://www.infoteca.cnptia.embrapa.br/infoteca/handle/doc/1096966 [accessed 27 Apr. 2020].

Costa-Lima J.L. 2020. Krameriaceae. In: Flora do Brasil 2020 em construção. Jardim Botânico, Rio de Janeiro. Available from http://floradobrasil.jbrj.gov.br/reflora/floradobrasil/FB8093 [accessed 22 Apr. 2020].

Ducke A. 1908. Contribution à la connaissance de la faune hyménoptérologique du Nord-Est du Brésil II. Hyménoptères récoletés dans l'État de Ceara en 1908. Revue d'Entomologie 27 (6): 57-87.

Esteves G. 2015. Melochia. In: Lista de espécies da flora do Brasil. Jardim Botânico, Rio de Janeiro. Available from: http://floradobrasil.jbrj.gov.br/jabot/floradobrasil/FB9106 [accessed 27 Apr. 2020].

Fabricius J.C. 1804. Systema Piezatorum secundum ordines, genera, species, adjectis synonymis, locis, observationibus, descriptionibus. Reichard, Brunsvigae. https://doi.org/10.5962/bhl.title.10490

Giannini T.C., Pinto C.E., Acosta A.L., Taniguchi M., Saraiva A.M. \& Alves-dos-Santos I. 2013. Interactions at large spatial scale: the case of Centris bees and floral oil producing plants in South America. Ecological Modelling 258: 74-78. https://doi.org/10.1016/j.ecolmodel.2013.02.032 
Klug J. 1810. Einige neue Piezatengattungen. Gesellschaft Naturforschender Freunde zu Berlin Magazin 4: 31-45.

Löwenberg-Neto P. 2014. Neotropical region: a shapefile of Morrone's (2014) biogeographical regionalisation. Zootaxa 3802: 300. https://doi.org/10.11646/zootaxa.3802.2.12

Machado I.C. 2004. Oil-Collecting bees and related plants: a review of the studies in the last twenty years and case histories of plants occurring in NE Brazil. In: Freitas B.M. \& Pereira J.O. (eds) Solitary Bees: Conservation, Rearing and Management for Pollination. Fortaleza.

Machado I.C. \& Sazima M. 2008. Pollination and breeding system of Melochia tomentosa L. (Malvaceae), a keystone floral resource in the Brazilian Caatinga. Flora 203: 484-490.

https://doi.org/10.1016/j.flora.2007.09.003

Mamede M.C.H. 2015. Stigmaphyllon. In: Lista de espécies da flora do Brasil. Jardim Botânico, Rio de Janeiro. Available from http://floradobrasil.jbrj.gov.br/jabot/floradobrasil/FB8945 [accessed 22 Apr. 2020].

Martins A.C. \& Alves-dos-Santos I. 2013. Floral-oil-producing Plantaginaceae species: geographical distribution, pollinator rewards and interactions with oil-collecting bees. Biota Neotropica 13: 77-89. https://doi.org/10.1590/S1676-06032013000400008

Martins A.C. \& Melo G.A.R. 2015. The new world oil-collecting bees Centris and Epicharis (Hymenoptera, Apidae): molecular phylogeny and biogeographic history. Zoologica Scripta 45: 22-33. https://doi.org/10.1111/zsc.12133

Martins H.O.L., Oliveira-Rebouças P. \& Ferreira V.S. 2018. Sleeping aggregation of an oil-collecting bee, Centris (Paracentris) xanthomelaena Moure \& Castro (Hymenoptera: Apidae: Centridini). Sociobiology 65: 770-772. https://doi.org/10.13102/sociobiology.v65i4.3452

Michener C.D. 1979. Biogeography of the bees. Annals of the Missouri Botanical Garden 66: 277-347. https://doi.org/10.2307/2398833

Michener C.D. 2007. The Bees of the World, $2^{\text {nd }}$ ed. Johns Hopkins University Press, Baltimore.

Moure J.S. 1950. Alguns agrupamentos novos de abelhas neotropicais. Dusenia 1: 385-396.

Moure J.S. \& Castro M. 2001. Uma nova espécie de Centris Fabricius (Hymenoptera, Apoidea, Anthophoridae) do Nordeste do Brasil. Revista Brasileira de Zoologia 18: 329-333. https://doi.org/10.1590/S0101-81752001000500028

Moure J.S., Melo G.A.R. \& Vivallo F. 2007. Centridini Cockerell \& Cockerell. In: Moure J.S., Urban D. \& Melo G.A.R. (eds) Catalogue of Bees (Hymenoptera, Apoidea) in the Neotropical Region. Sociedade Brasileira de Entomologia, Curitiba.

Morrone J.J. 2014. Biogeographical regionalisation of the Neotropical region. Zootaxa 3782: 1-110. https://doi.org/10.11646/zootaxa.3782.1.1

Pigozzo C.M. \& Viana B.F. 2010. Estrutura da rede de interações entre flores e abelhas em ambiente de Caatinga. Oecologia Australis 14: 100-114. https://doi.org/10.4257/oeco.2010.1401.04

Prevedello J.A. \& Carvalho C.J.B. 2006. Conservação do Cerrado brasileiro: o método pan-biogeográfico como ferramenta para a seleção de áreas prioritárias. Nature Conservation 4: 39-57. Available from https://www.researchgate.net/publication/235869535 [acessed 20 Jan. 2020].

Rodarte A.T.A., Silva F.O. \& Viana B.F. 2008. A flora melitófila de uma área de dunas com vegetação de caatinga, Estado da Bahia, Nordeste do Brasil. Acta Botanica Brasilica 22: 301-312. https://doi.org/10.1590/S0102-33062008000200001 
Roig-Alsina A. 2000. Claves para las especies argentinas de Centris (Hymenoptera, Apidae), con descripción de nuevas especies y notas sobre distribución. Revista del Museo Argentino de Ciencias Naturales 2 (2): 171-193.

Silva E.M. 2014. Lista de espécies de Apidae (Hymenoptera) do semiárido com base na literatura especializada. In: Bravo F. \& Calor A. (eds) Artrópodes do Semiárido Biodiversidade e Conservação: 181-202. Printmídia, Feira de Santana. Available from https://www.researchgate.net/publication/265726779 [accessed 10 Sep. 2019].

Silveira F.A., Melo G.A.R. \& Almeida E.A.B. 2002. Abelhas Brasileiras Sistemática e Identificação. Fundação Araucária, Belo Horizonte.

Siqueira K.M.M., Martins C.F., Kiill L.H.P. \& Silva L.T. 2011. Estudo comparativo da polinização em variedades de aceroleiras (Malpighia emarginata DC, Malpighiaceae). Revista Caatinga 24: 18-25. Available from https://www.researchgate.net/publication/277211168 [accessed 16 Jun. 2021].

Snelling R.R. 1966. The taxonomy and nomenclature of some North American bees of the genus Centris with descriptions of new species. Contributions in Science, Los Angeles 112: 1-33.

Snelling R.R. 1984. Studies on the taxonomy and distribution of American Centridine bees (Hymenoptera: Anthophoridae). Contributions in Science, Los Angeles 347: 1-69.

Souza V.C. \& Bortoluzzi R.L.C. 2015. Chamaecrista. In: Lista de espécies da flora do Brasil. Jardim Botânico, Rio de Janeiro. Available from http://floradobrasil.jbrj.gov.br/jabot/floradobrasil/FB27838 [accessed 22 Apr. 2020].

Souza V.C., Scatigna A.V., Hassemer G. \& Colletta G.D. 2020. Angelonia campestris. In: Flora do Brasil $2020 \mathrm{em}$ construção. Jardim Botânico, Rio de Janeiro. Available from http://floradobrasil.jbrj.gov.br/reflora/floradobrasil/FB25954 [accessed 22 Apr. 2020].

Urban D. 2003. Catálogo das abelhas publicadas por Jesus Santiago Moure. In: Melo G.A.R \& Alvesdos-Santos I. (eds) Apoidea Neotropica: Homenagem aos 90 Anos de Jesus Santiago Moure: 11-43. Editora UNESC, Criciúma.

Vivallo F. 2013. Revision of the bee subgenus Centris (Wagenknechtia) Moure, 1950 (Hymenoptera: Apidae: Centridini). Zootaxa 3683: 501-537. https://doi.org/10.11646/zootaxa.3683.5.1

Vivallo F. 2020. The Oil-Collecting Bees of Centris (Paracentris): Taxonomy-Biodiversity-Distribution. Editora Publ!t, Rio de Janeiro.

Vivallo F. \& Melo G.A.R. 2009. Taxonomy and geographic distribution of the species of Centris of the hyptidis group (Hymenoptera: Apidae: Centridini), with description of a new species from central Brazil. Zootaxa 2075: 33-44. https://doi.org/10.11646/zootaxa.2075.1.2

Vivallo F. \& Zanella F.C.V. 2012. A new species of Centris (Paracentris) Cameron, 1903 from northeastern Brazil, with a key for the Centris species of the Caatinga region (Hymenoptera: Apidae). Zootaxa 3298: 1-16. https://doi.org/10.11646/zootaxa.3298.1.1

Vogel S. \& Machado I.C. 1991. Pollination of four sympatric species of Angelonia (Scrophulariaceae) by oil-collecting bees in NE. Brazil. Plant Systematics and Evolution 178: 153-178.

Werneck F.P. 2011. The diversification of eastern South American open vegetation biomes: historical biogeography and perspectives. Quaternary Science Reviews 30: 1630-1648. https://doi.org/10.1016/j.quascirev.2011.03.009

Xavier J.R.S., Santana E.G.R., Silva T.S. \& Silva A.C.R.A. 2016. Diversidade de abelhas em áreas de Caatinga strictu sensu. In: Anais do I Congresso Internacional de Diversidade do Semiárido. Available from http://www.editorarealize.com.br/artigo/visualizar/23715 [accessed 23 Apr. 2020]. 
Zanella F.C.V. 2002. Sistemática, filogenia e distribuição geográfica das espécies sul-americanas de Centris (Paracentris) Cameron, 1903 e de Centris (Penthemisia) Moure, 1950, incluindo uma análise filogenética do grupo Centris, sensu Ayala, 1998 (Hymenoptera: Apoidea: Centridini). Revista Brasileira de Entomologia 46: 435-488. https://doi.org/10.1590/S0085-56262002000400001

Zanella F.C.V. 2003. Abelhas da Estação Ecológica do Seridó (Serra Negra do Norte, $\mathrm{RN})$ : aportes ao conhecimento da diversidade, abundância e distribuição espacial das espécies na Caatinga. In: Melo G.A.R. \& Alves-dos-Santos I. (eds) Apoidea Neotropica: Homenagem aos 90 Anos de Jesus Santiago Moure: 231-240. Editora UNESC, Criciúma. Available from https://www.researchgate.net/publication/235007025 [accessed 16 Jun. 2021].

Zanella F.C.V. 2011. Evolução da biota da diagonal de formações abertas secas da América do Sul. In: Carvalho C.J.B. \& Almeida E.A.B. (eds) Biogeografia da América do Sul. Padrões e Processos: 198220. Editora Roca, São Paulo, SP. Available from https://www.researchgate.net/publication/350499172 [accessed 16 Jun. 2021].

Zanella F.C.V. \& Vivallo F. 2009. A new species of the bee genus Centris from Peru (Hymenoptera: Apidae). Zootaxa 2175: 66-68.

Manuscript received: 22 June 2020

Manuscript accepted: 13 April 2021

Published on: 14 July 2021

Topic editor: Gavin Broad

Desk editor: Charlotte Gérard

Printed versions of all papers are also deposited in the libraries of the institutes that are members of the EJT consortium: Muséum national d'histoire naturelle, Paris, France; Meise Botanic Garden, Belgium; Royal Museum for Central Africa, Tervuren, Belgium; Royal Belgian Institute of Natural Sciences, Brussels, Belgium; Natural History Museum of Denmark, Copenhagen, Denmark; Naturalis Biodiversity Center, Leiden, the Netherlands; Museo Nacional de Ciencias Naturales-CSIC, Madrid, Spain; Real Jardín Botánico de Madrid CSIC, Spain; Zoological Research Museum Alexander Koenig, Bonn, Germany; National Museum, Prague, Czech Republic. 